\title{
Comparison of nanoscale zero-valent iron, fenton, and photo-fenton processes for degradation of pesticide 2,4-dichlorophenoxyacetic acid in aqueous solution
}

\author{
Fatma Midik Ertosun ${ }^{1} \cdot$ Kemal Cellat $^{1,2} \cdot$ Orkide Eren $^{1} \cdot$ Şermin Gül ${ }^{1} \cdot$ Erdal Kuşvuran $^{1} \cdot$ Fatih Şen $^{2}$
}

Received: 14 August 2019 / Accepted: 22 October 2019/ Published online: 25 October 2019

(c) Springer Nature Switzerland AG 2019

\begin{abstract}
Nanoscale zero-valent iron (nZVI) products are highly applicable in groundwater, industrial water, and wastewater treatment due to the high reduction properties, the small size of particles in the range of nanometers, large surface area, and high reactivity on most toxic contaminants. The ultimate aim of this study is to evaluate the removal performance of 2,4-dichlorophenoxyacetic acid (2,4-D) by nanoscaled ZVI particles. Synthesized nanoscale iron particles were characterized by X-ray diffraction and scanning electron microscopy (SEM). According to SEM images of nZVI, the particle size was under $100 \mathrm{~nm}$ in diameter. The specific surface area was measured by the $\mathrm{N}_{2} / \mathrm{BET}$ method and determined as $44.7 \pm 0.4 \mathrm{~m}^{2} / \mathrm{g}$. The influences of $\mathrm{nZVI}$ dosage, initial $\mathrm{pH}$ and effects of different processes were examined by batch experiments. Results were compared with Fenton and photo-Fenton processes and they showed that under optimized conditions, degradation by $\mathrm{nZVI}$ is more effective than Fenton and photo-Fenton reactions and a promising candidate for 2,4-D remediation.
\end{abstract}

Keywords Nano zero-valent iron $\cdot$ Pesticide $\cdot 2,4$-Dichlorophenoxyacetic acid $\cdot$ Remediation $\cdot$ Nanomaterials

\section{Introduction}

Pesticides and herbicides have been extensively used in agrochemical industries in order to supply increasing food demand. Pesticides, as high soluble materials, can contaminate the natural water sources after using the field. As a result of this case, a significant increase in the amount of different agrochemicals in natural sources has been observed. Some of these chemicals are persisted and have essential environmental adverse effects on aquatic ecosystems and accumulate in the human body and animals. In addition, there are also negative economic and social impacts related to agrochemical contamination of the aquatic environment. Due to the hydrophobic nature of organic pollutants, their remediation has become a growing concern. Recently, researchers focused on to assess the probable harm of these pesticides and herbicides toward the earth's ecosystem and human health [1-4].

Among the various agrochemicals that used at present, 2,4-dichlorophenoxyacetic acid (2,4-D), the herbicide, is extensively utilized in gardening agricultural practice due to its low cost [5]. It is relatively highly soluble in water and poorly biodegradable. 2,4-D free acid has a low soil adsorption coefficient; thus, it can permeate the soil, and possibly to transfer to groundwater by leakage $[6,7]$. It is considered as moderately toxic by the World Health Organization (WHO), and the maximum acceptable concentration is $100 \mathrm{ppb}$ in drinking water [8].

$\triangle$ Kemal Cellat, kcellat@gmail.com; $\bowtie$ Fatih Şen, fatih.sen@dpu.edu.tr | ${ }^{1}$ Department of Chemistry, Faculty of Science and Letters, Cukurova University, Adana, Turkey. ${ }^{2}$ Sen Research Group, Department of Biochemistry, Faculty of Arts and Science, Dumlupınar University, Evliya Çelebi Campus, 43100 Kutahya, Turkey. 
Advanced oxidation processes (AOPs) are suited to the cleaning of contaminated waters by dissolved organic contaminants such as aromatic compounds [9], dyes [10], pharmaceuticals [11], detergents [12], herbicides [13], pesticides [14, 15], etc. Nanoscale zero-valent iron (nZVI) quickly reacts with oxygen for the production of strong oxidants. Initially, surfaces of $\mathrm{Fe}^{0}$ transfer two electrons to $\mathrm{O}_{2}$, resulting in oxidized the ferrous iron $\left(\mathrm{Fe}^{2+}\right.$ ) and produced $\mathrm{H}_{2} \mathrm{O}_{2}(\mathrm{Eq} 1)$. The $\mathrm{H}_{2} \mathrm{O}_{2}$ can be reduced to water molecules by additional two-electron transfer from ZVI (Eq. 2) [16]. In the Fenton reaction, $\mathrm{Fe}^{2+}$ is oxidized to produce hydroxyl radicals $(\cdot \mathrm{OH})$ which have strong oxidizing ability against to many organic compounds (Eq. 3) The formation of $\mathrm{OH}$ radical mostly occurs via Eq. 4 in the photo-Fenton process, the reduction of $\mathrm{Fe}^{3+}$ to $\mathrm{Fe}^{2+}$ takes place, in this process. $\mathrm{Fe}^{3+}$ catalysis the generation of $\mathrm{OH}$ radicals with the UV light irradiation [17].

$\mathrm{Fe}^{0}+\mathrm{O}_{2}+2 \mathrm{H}^{+} \rightarrow \mathrm{Fe}^{2+}+\mathrm{H}_{2} \mathrm{O}_{2}$

$\mathrm{Fe}^{0}+\mathrm{H}_{2} \mathrm{O}_{2}+2 \mathrm{H}^{+} \rightarrow \mathrm{Fe}^{2+}+2 \mathrm{H}_{2} \mathrm{O}$

$\mathrm{Fe}^{2+}+\mathrm{H}_{2} \mathrm{O}_{2} \rightarrow \mathrm{Fe}^{3+}+\cdot \mathrm{OH}+\mathrm{OH}^{-}$

$\mathrm{Fe}^{3+}+\mathrm{H}_{2} \mathrm{O}+\mathrm{h} v \rightarrow \mathrm{Fe}^{2+}+\mathrm{H}^{+}+\cdot \mathrm{OH}$

In Fenton reaction, quick consumption of $\mathrm{H}_{2} \mathrm{O}_{2}$, incomplete pollutants mineralization, loss of Fe ions, limited $\mathrm{pH}$ range, low degradation ratio of some chemicals are considered as major problems [18]. For solving related problems, alternative methods have been offered.

Recently, the using of $\mathrm{nZVI}$ has reported for the remediation of environmental pollutants. nZVI particles, which have high surface reactivity due to large surface areas, provide a cost-effective solution on the most challenging environmental remediation problems [19]. In the literature, using of $\mathrm{nZVI}$ particles are reported as very effective method for detoxification and transformation of a wide range of environmental pollutants, such as nitroaromatics [20], arsenic [21], heavy metals [22], nitrate [23], chlorinated organic compounds [24], dyes [25], and phenol [26]. Similarly, modified nanoscale iron particles, including supported and catalyzed particles, was used to make enhancements in terms of the remediation efficiency and reaction time [27-29].

The objective of this study is to make a comparison of the 2,4-D remediation efficiencies of $n Z V I$, Fenton, and photo-Fenton methods and obtain the optimum conditions. For this aim, nZVI ( $<100 \mathrm{~nm})$ was synthesized by borohydride reduction method in laboratory scale. Results showed that using $\mathrm{nZVI}$ is an effective method for a faster and efficient method for the removal of 2,4-D.

\section{Materials and methods}

\subsection{Materials}

2,4-Dichlorophenoxyacetic (>99.9\%) acid was obtained from Merck. The chemical structure of 2,4-D was illustrated in Fig. 1. Sodium borohydride and ferric chloride $\left(\mathrm{FeCl}_{3} \cdot 6 \mathrm{H}_{2} \mathrm{O}\right)$ were purchased from Merck. The methanol and acetonitrile for high-performance liquid chromatography (HPLC) were supplied by Merck. All the other chemicals were analytical grade and used without further purification.

\subsection{Synthesis of $\mathrm{nZVI}$}

Colloidal particles of $\mathrm{ZVI}$ were synthesized by the following procedure: $0.1 \mathrm{M} \mathrm{FeCl}_{3} \cdot 6 \mathrm{H}_{2} \mathrm{O}$ (1 L; Merck, $\left.98 \%\right)$, solution was prepared under $\mathrm{N}_{2}$ atmosphere at room conditions and then an aqueous solution of $0.16 \mathrm{M} \mathrm{NaBH}_{4}(1 \mathrm{~L} ; 98 \%$,
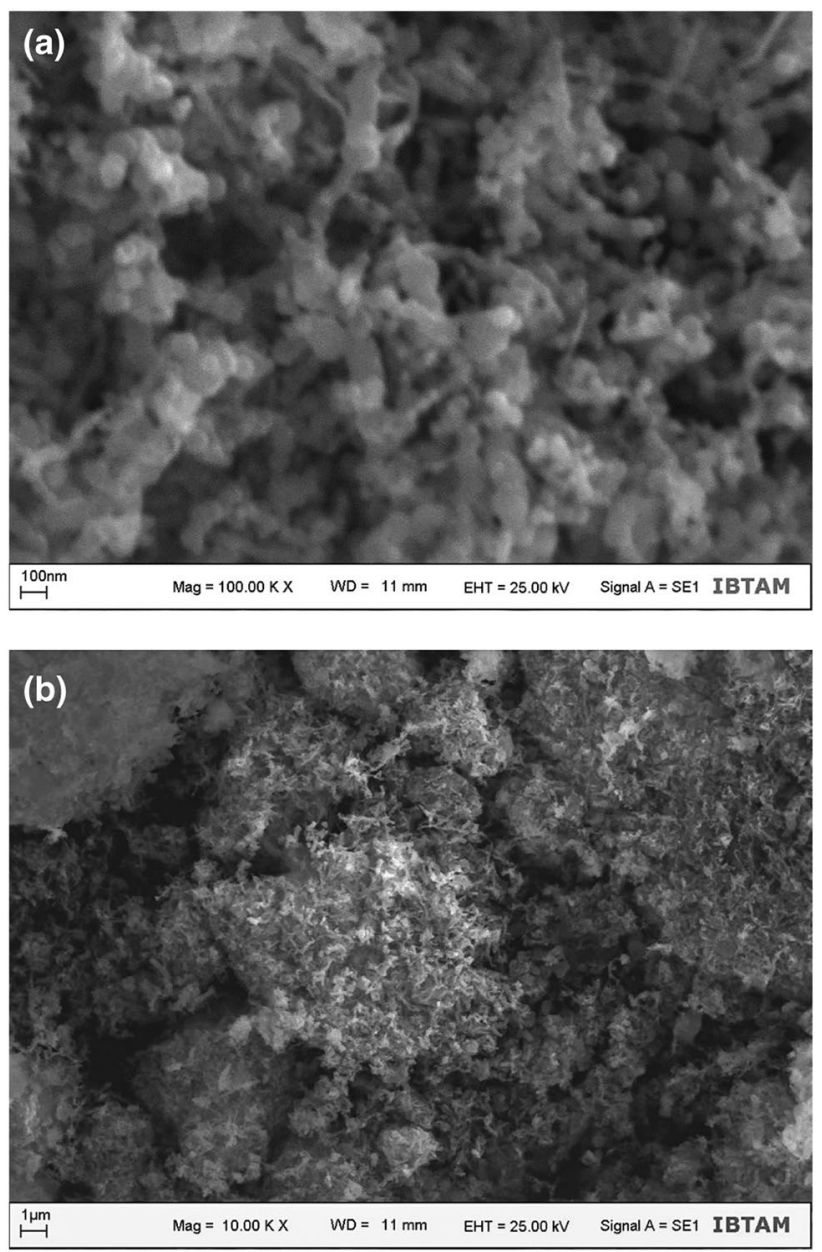

Fig. 1 SEM image of $n Z V I a 100 k X, b \times 10 k$ magnification 
Merck) was added dropwise to this prepared solution as described by Wang and Zhang [30]. In this reaction, the ferric iron $\left(\mathrm{Fe}^{3+}\right)$ was reduced to nanosized zero-valent iron $\left(\mathrm{Fe}^{0}\right)$ with the help of sodium borohydride as a strong reducing agent. Chemical precipitation was given below:

$\mathrm{Fe}\left(\mathrm{H}_{2} \mathrm{O}\right)_{6}^{3+}+3 \mathrm{BH}_{4}^{-}+3 \mathrm{H}_{2} \mathrm{O} \rightarrow \mathrm{Fe}^{0} \downarrow+3 \mathrm{~B}(\mathrm{OH})_{3}+10.5 \mathrm{H}_{2}$

The solution was kept stirring for another $10 \mathrm{~min}$. Then, synthesized $\mathrm{nZVI}$ particles were separated from the liquid phase and washed with three times using $20 \mathrm{~mL}$ of absolute methanol to prevent rapid oxidation. The synthesized nanoparticles were dried under vacuum at $50^{\circ} \mathrm{C}$ for about $12 \mathrm{~h}$. The resulting material was gray-black solid powder and preserved in nitrogen atmosphere.

\subsection{Characterization of nZVI}

Synthesized nZVI nanoparticles were characterized by scanning electron microscopy (SEM), Brunauer-Emmett-Teller (BET)- $\mathrm{N}_{2}$ adsorption, and X-ray diffraction (XRD) techniques.

In order to investigate surface morphology and particle size of the $n Z V I$, scanning electron microscopy (SEM) (JEOL JSM-5500 Japan) at an accelerating voltage of $10 \mathrm{kV}$ was used.

The crystal structure was examined by using Rigaku Miniflex X-ray diffractometer (XRD). Prior to the XRD analysis, nZVI samples were dried in a vacuum freeze drier (Dura-Dry VP190D). The analysis was conducted at $40 \mathrm{kV}$ and $40 \mathrm{~mA}$ with copper $\mathrm{K}$-a radiation.

Specific surface area (BET area) and pore volumes of nanoparticles were measured using the nitrogen adsorption method using Tristar 3000 (Micrometritics, USA) model surface analyzer.

\subsection{Batch experiments}

The aqueous pesticide solutions were prepared at an initial concentration of $0.1 \mathrm{mM}$ of 2,4-D. For the comparison of the removal efficiencies of Fenton, photo-Fenton, and $\mathrm{nZVI}$ process in aqueous solution, batch experiments were done. $500 \mathrm{~mL}$ of pesticide solution was moved to a beaker flask with a volume of $600 \mathrm{~mL}$, and then $0.2 \mathrm{~g} / \mathrm{L}, 0.5 \mathrm{~g} / \mathrm{L}$, or $1 \mathrm{~g} / \mathrm{L}$ of $\mathrm{nZVI}$ was added. A shaker was used to stir the beaker. The experiments were performed at room temperature. Samples were collected after 0, 10, 20, 30, 40, $50,60,80,100$, and 120 min of treatment and centrifuged at $6000 \mathrm{rpm}$ for $5 \mathrm{~min}$.

The residual concentrations of 2,4-D were quantified by high-performance liquid chromatography (HPLC), Shimadzu Class VP HPLC equipped with a C-18 column (ODS2 $25 \mathrm{~cm} \times 4.6 \mathrm{~mm} \times 5 \mathrm{~mm}$ ) and UV detector, before and after treatment by $\mathrm{nZVI}$. The detection was performed at a wavelength of $284 \mathrm{~nm}$. The mobile phase of HPLC was composed of methanol, acetonitrile, and water $\left(1 \% \mathrm{H}_{3} \mathrm{PO}_{4}\right)$ (40:40:20). The residual concentrations of 2,4-D were also qualified by observing the changes of HPLC chromatogram to investigate the effect of initial $\mathrm{pH}$ on removal of 2,4-D by $\mathrm{nZVl}$; the pesticide solution was adjusted to $\mathrm{pH}$ $3, \mathrm{pH} 7$, and $\mathrm{pH} 11$ by adding $0.1 \mathrm{M} \mathrm{HCl}$ and $\mathrm{NaOH}$ before the treatment.

\section{Results and discussion}

\subsection{Characterization of $n Z V I$}

The surface morphology of $\mathrm{nZVI}$ particles was analyzed by SEM, which showed that particle size under $100 \mathrm{~nm}$ in diameter (Fig. 1). The SEM image resembles the previously reported ones in the literature [31,32]. The $\mathrm{nZVI}$ particles are in nanosphere form, and those are in contact with one another. The surface of $n Z \mathrm{VI}$ was rough and formed chain-like aggregates, but the particles with diameters of $40-60 \mathrm{~nm}$ can be a discerned form. Due to magnetic dipole-dipole interactions and large surface area of nanoparticles, agglomeration can be occurred [33].

$\mathrm{X}$-ray diffraction (XRD) was employed to investigate the mineral composition of $n Z V I$. X-ray diffractogram of $\mathrm{nZVI}$ particles is illustrated in Fig. 2. The apparent peak at the $2 \theta$ of $44.575^{\circ}$ showed the presence and crystalline structure of $\mathrm{ZVI}$ particles. No signal was observed for the iron oxides (hematite, $\mathrm{Fe}_{2} \mathrm{O}_{3}$ or magnetite, $\mathrm{Fe}_{3} \mathrm{O}_{4}$ ). This might be due to the fact that they are in very low concentration that below the detection limit of XRD. According to characteristic peak in XRD diffractogram, the $\mathrm{nZVI}$ nanoparticles have body-centered cubic (bcc) $a-\mathrm{Fe}^{0}$. Moreover, the crystallite size was calculated using

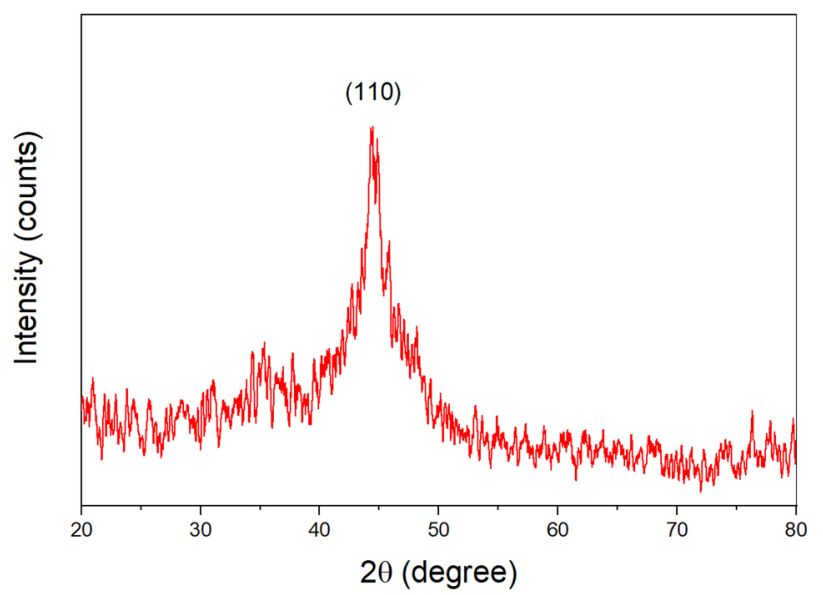

Fig. 2 X-ray diffractogram of ZVI sample 
Scherer equation and found to be $14 \mathrm{~nm}$, in accordance with SEM results.

The specific surface area value of the $\mathrm{nZVI}$ was determined as $44.7 \pm 0.4 \mathrm{~m}_{2} / \mathrm{g}$ by the BET- $\mathrm{N}_{2}$ method. The BET surface area of iron nanoparticles in this study was in the range of synthesized by other researchers. In the literature, it was reported that BET surface areas found as $25 \mathrm{~m}^{2} / \mathrm{g}$ [34], $29.67 \mathrm{~m}^{2} / \mathrm{g}$ [35], $10.5 \mathrm{~m}^{2} / \mathrm{g}$ [36], and $36.5 \mathrm{~m}^{2} / \mathrm{g}$ [37]. However, the specific surface area of commercial Fe powder $(<10 \mu)$ is $0.9 \mathrm{~m}^{2} / \mathrm{g}$ [30], which is very small compared to nanoscale iron reported in the literature. The iron surface is the active site for the remediation. Hence, the samples, which have a higher surface area, mean higher remediation capacity.

\subsection{Effect of $n Z V I$ dosage}

Experiments for determining the effect of $n Z \mathrm{VI}$ dosage on the remediation rate of 2,4-D were conducted by utilizing different concentrations of $\mathrm{nZVI}(0.2 \mathrm{~g} / \mathrm{L}$, $0.5 \mathrm{~g} / \mathrm{L}$, and $1.0 \mathrm{~g} / \mathrm{L}$ ). The results are shown in Fig. 3. Adding increasing amounts of $\mathrm{nZVI}$ particles exponentially increased the remediation efficiency of 2,4-D. However, after $0.5 \mathrm{~g} / \mathrm{L} \mathrm{nZVI}$ dosage, a significant removal was not observed and this dosage preferred as optimum dosage due to cost-effectiveness. nZVI has significant importance as an electron donor for starting the degradation of 2,4-D. Higher dosage of nZVI means more source of $\mathrm{Fe}(\mathrm{II})$ ions. Additionally, a high density of $\mathrm{nZVI}$ allows enhanced active areas where the reaction occurs. Thus, the efficiency of the reaction is increased.

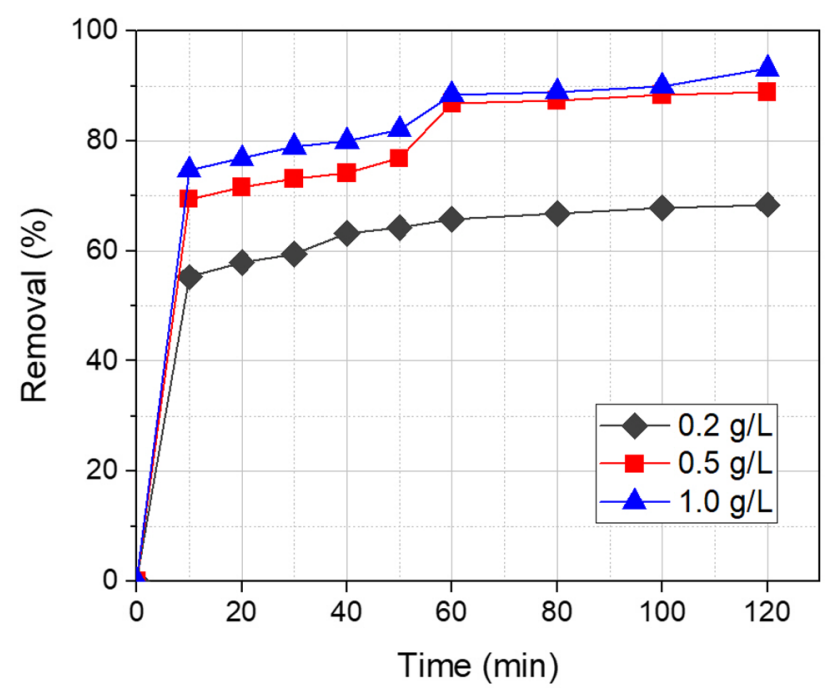

Fig. 3 Effect of nZVI dosage

\subsection{Effect of $\mathrm{pH}$}

The effect of initial pH in the Fenton method is a critical parameter [38]. It was investigated at a pH range of 3 to 11 . Experiments were done by the same conditions while the only variable was the $\mathrm{pH}$ of the solution. It was observed that the degradation rate was increased by lowering $\mathrm{pH}$ value. However, after $\mathrm{pH} 3$, the efficiency of degradation tends to decrease. This can be explained by the protonation of the $\mathrm{nZVI}$ surface with lower $\mathrm{pH}$ values. The previous studies also reported that the optimum $\mathrm{pH}$ is in the range 3-4 for high removal efficiency $[39,40]$. In light of this data, it can be concluded that the optimum $\mathrm{pH}$ for the degradation is $\mathrm{pH} 3$ (Fig. 4). Additionally, the initial pH had an essential role in the removal efficiency during the first $10 \mathrm{~min}$. Nevertheless, this effect diminished with longer reaction times. At the initial $\mathrm{pH} 3$, solution of 2,4-D was removed at higher efficiencies in shorter reaction time compared to other $\mathrm{pH}$ values studied.

\subsection{Effect of degradation processes}

The removal efficiency of $\mathrm{nZVI}$, Fenton and photo-Fenton processes was compared in Fig. 5. The ratio of $\mathrm{Fe}^{2+}: \mathrm{H}_{2} \mathrm{O}_{2}$ was selected as 1:5. This ratio was determined as the optimum ratio in the course of Fenton and photo-Fenton experiments [41]. The degradation of 2,4-D with nZVI has been more successful than the other two methods. This is due to the high catalytic activity of nZVI toward to degradation of 2,4-D. Using the nZVI method, the removal of $89 \%$ was achieved, while Fenton and photoFenton remained $67 \%$ and $76 \%$, respectively. Among the processes used in this study, the order of efficiency

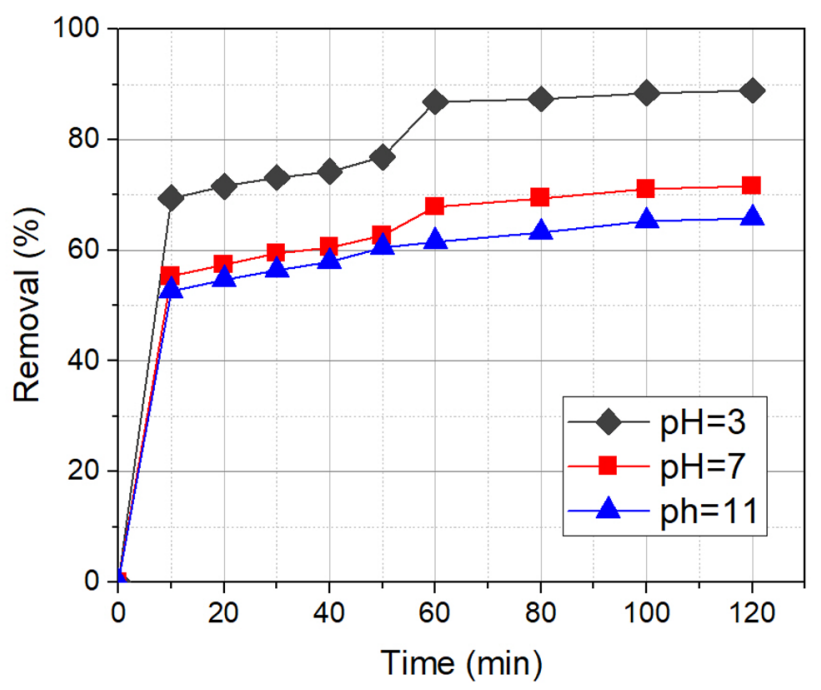

Fig. 4 Effect of initial pH 


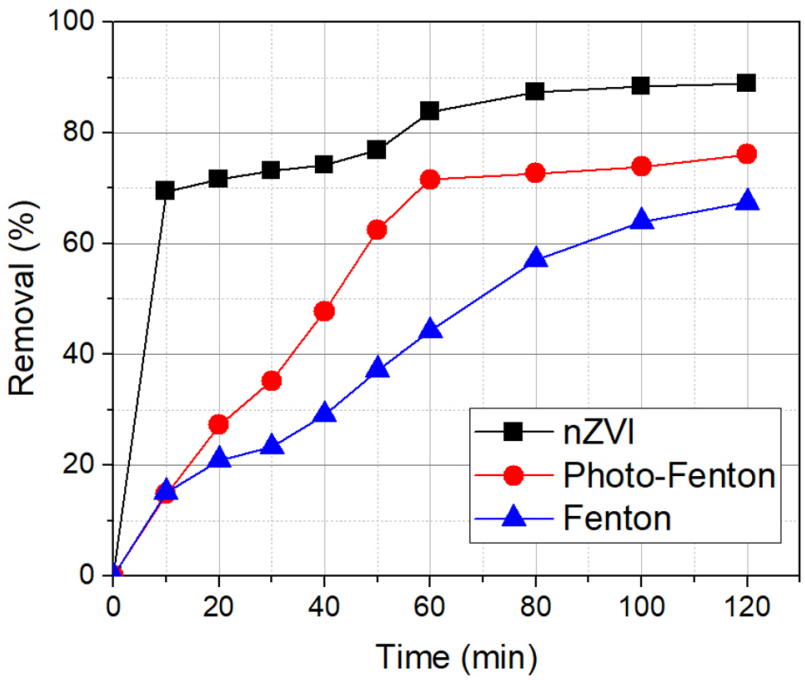

Fig. 5 Comparison of degradation processes

in removing 2,4-D was found in the following order: $\mathrm{nZVl}>$ photo-Fenton $>$ Fenton.

\section{Conclusion}

$\mathrm{nZVI}$ particles were synthesized in aqueous medium under $\mathrm{N}_{2}$ atmosphere. SEM, XRD, and BET- $\mathrm{N}_{2}$ techniques were employed for the characterization of the $\mathrm{nZVI}$. Results indicated that the prepared particles were under $100 \mathrm{~nm}$ in diameter, a surface area of $44.7 \mathrm{~m}^{2} / \mathrm{g}$ and had a chain-like structure. Reductive dechlorination by $\mathrm{nZVI}$ was the primary process in the destruction of 2,4-D. The results support that the main factors on the removal rate are $\mathrm{nZVI}$ dosage and initial $\mathrm{pH}$ solution. These variables have a significant influence on the degradation rate. The removal efficiency of 2,4-D increased with the increasing dosage of ZVI nanoparticles. However, after certain levels of $\mathrm{nZVI}$ concentration, the removal efficiency was raised slightly. In order to be cost effective, the optimal nZVI dosage was selected as $0.5 \mathrm{~g} / \mathrm{L}$. Changing the $\mathrm{pH}$ from 11 to 3 increased the degradation rate of 2,4-D by $n Z V I$. Results showed that using $\mathrm{nZVI}$ is an effective method to remediate water and soil contaminated with 2,4-D. nZVI provides not only active sites and very high surface area but also the source of Fe(II). Under optimized conditions, degradation by $\mathrm{nZVI}$ is more effective than Fenton and photo-Fenton processes, and the results support that $\mathrm{nZVI}$ is a convenient candidate for 2,4-D remediation. The $\mathrm{nZVI}$ process is suggested as an innovative technology in removing chlorinated pesticides from wastewater and also efficient treatment options in wastewater treatment technology.
Funding This research was funded by the Academic and Research Projects Unit of Çukurova University (BAP Project No. FEF2010YL13), authors gratefully appreciate this support.

\section{Compliance with ethical standards}

Conflict of interest The authors declare that they have no conflict of interest.

\section{References}

1. Iglesias $\mathrm{O}$, de Dios MAF, Tavares $T$, Sanromán MA, Pazos M (2015) Heterogeneous electro-Fenton treatment: preparation, characterization and performance in groundwater pesticide removal. J Ind Eng Chem 27:276-282. https://doi.org/10.1016/J. JIEC.2014.12.044

2. Bhaskar S, Manu B, Sreenivasa MY (2019) Bacteriological synthesis of iron hydroxysulfate using an isolated Acidithiobacillus ferrooxidans strain and its application in ametryn degradation by Fenton's oxidation process. J Environ Manage 232:236-242. https://doi.org/10.1016/J.JENVMAN.2018.11.048

3. Njoku VO, Asif M, Hameed BH (2015) 2,4-Dichlorophenoxyacetic acid adsorption onto coconut shell-activated carbon: isotherm and kinetic modeling. Desalin Water Treat 55:132-141. https:// doi.org/10.1080/19443994.2014.911708

4. Cai J, Zhou M, Yang W, Pan Y, Lu X, Serrano KG (2018) Degradation and mechanism of 2,4-dichlorophenoxyacetic acid $(2,4-D)$ by thermally activated persulfate oxidation. Chemosphere 212:784-793. https://doi.org/10.1016/J.CHEMOSPHER E.2018.08.127

5. Yang X, Chen J, Liu H, Li X, Zhong S (2019) Molecularly imprinted polymers based on zeolite imidazolate framework-8 for selective removal 2,4-dichlorophenoxyacetic acid. Colloids Surfaces A Physicochem Eng Asp 570:244-250. https://doi.org/10.1016/j. colsurfa.2019.03.038

6. Boivin A, Amellal S, Schiavon M, van Genuchten MT (2005) 2,4-Dichlorophenoxyacetic acid (2,4-D) sorption and degradation dynamics in three agricultural soils. Environ Pollut 138:9299. https://doi.org/10.1016/J.ENVPOL.2005.02.016

7. Yang Z, Xu X, Dai M, Wang L, Shi X, Guo R (2018) Combination of bioaugmentation and biostimulation for remediation of paddy soil contaminated with 2,4-dichlorophenoxyacetic acid. J Hazard Mater 353:490-495. https://doi.org/10.1016/j.jhazm at.2018.04.052

8. Akpan UG, Hameed BH (2011) Photocatalytic degradation of 2,4-dichlorophenoxyacetic acid by $\mathrm{Ca}-\mathrm{Ce}-\mathrm{W}-\mathrm{TiO} 2 \mathrm{com}-$ posite photocatalyst. Chem Eng J 173:369-375. https://doi. org/10.1016/j.cej.2011.07.069

9. Eren O, Gul S, Kusvuran E, Cellat K, Ertosun FM (2015) Treatment of olive mill wastewater by catalytic ozonation using activated carbon prepared from olive stone by $\mathrm{KOH}$. Asian J Chem 27:4106-4110. https://doi.org/10.14233/ajchem.2015.19106

10. Nidheesh PV, Zhou M, Oturan MA (2018) An overview on the removal of synthetic dyes from water by electrochemical advanced oxidation processes. Chemosphere 197:210-227. https://doi.org/10.1016/j.chemosphere.2017.12.195

11. Kanakaraju D, Glass BD, Oelgemöller M (2018) Advanced oxidation process-mediated removal of pharmaceuticals from water: a review. J Environ Manage 219:189-207. https://doi. org/10.1016/j.jenvman.2018.04.103

12. Khan S, Sayed M, Sohail M, Shah LA, Raja MA (2019) Advanced oxidation and reduction processes. Adv Water Purif Tech. https ://doi.org/10.1016/b978-0-12-814790-0.00006-5 
13. Kovács K, Farkas J, Veréb G, Arany E, Simon G, Schrantz K, Dombi A, Hernádi K, Alapi T (2016) Comparison of various advanced oxidation processes for the degradation of phenylurea herbicides. J Environ Sci Heal Part B Pestic Food Contam Agric Wastes 51:205-214. https://doi.org/10.1080/03601234.2015.1120597

14. Cheng M, Zeng G, Huang D, Lai C, Xu P, Zhang C, Liu Y (2016) Hydroxyl radicals based advanced oxidation processes (AOPs) for remediation of soils contaminated with organic compounds: a review. Chem Eng J 284:582-598. https://doi.org/10.1016/j. cej.2015.09.001

15. Parker AM, Lester Y, Spangler EK, von Gunten U, Linden KG (2017) UV/H2O2 advanced oxidation for abatement of organophosphorous pesticides and the effects on various toxicity screening assays. Chemosphere 182:477-482. https://doi.org/10.1016/j. chemosphere.2017.04.150

16. Škodič L, Vajnhandl S, Volmajer Valh J, Željko T, Vončina B, Lobnik A (2017) Comparative study of reactive dyes oxidation by $\mathrm{H}_{2} \mathrm{O}_{2} /$ UV, $\mathrm{H}_{2} \mathrm{O}_{2} / \mathrm{UV} / \mathrm{Fe}^{2+}$ and $\mathrm{H}_{2} \mathrm{O}_{2} / \mathrm{UV} / \mathrm{Fe}^{\circ}$ processes. Ozone Sci Eng 39:14-23. https://doi.org/10.1080/01919512.2016.1229173

17. Chen Y, Liu Z, Wang Z, Xue M, Zhu X, Tao T (2011) Photodegradation of propranolol by $\mathrm{Fe}(\mathrm{III})$-citrate complexes: kinetics, mechanism and effect of environmental media. J Hazard Mater 194:202-208. https://doi.org/10.1016/j.jhazmat.2011.07.081

18. Pignatello JJ, Oliveros E, MacKay A (2006) Advanced oxidation processes for organic contaminant destruction based on the fenton reaction and related chemistry. Crit Rev Environ Sci Technol 36:1-84. https://doi.org/10.1080/10643380500326564

19. Fu F, Dionysiou DD, Liu H (2014) The use of zero-valent iron for groundwater remediation and wastewater treatment: a review. J Hazard Mater 267:194-205. https://doi.org/10.1016/j.jhazm at.2013.12.062

20. Yin W, Wu J, Li P, Wang X, Zhu N, Wu P, Yang B (2012) Experimental study of zero-valent iron induced nitrobenzene reduction in groundwater: the effects of $\mathrm{pH}$, iron dosage, oxygen and common dissolved anions. Chem Eng J 184:198-204. https://doi. org/10.1016/j.cej.2012.01.030

21. Kanel SR, Greneche J-M, Choi H (2006) Arsenic(V) removal from groundwater using nano scale zero-valent iron as a colloidal reactive barrier material. Environ Sci Technol 40:2045-2050

22. Li S, Wang W, Liang F, Zhang WX (2017) Heavy metal removal using nanoscale zero-valent iron (nZVI): theory and application. J Hazard Mater 322:163-171. https://doi.org/10.1016/j.jhazm at.2016.01.032

23. Su Y, Adeleye AS, Huang Y, Sun X, Dai C, Zhou X, Zhang Y, Keller AA (2014) Simultaneous removal of cadmium and nitrate in aqueous media by nanoscale zerovalent iron ( $\mathrm{nZVI})$ and Au doped nZVI particles. Water Res 63:102-111. https://doi. org/10.1016/j.watres.2014.06.008

24. Shih YH, Hsu CY, Su YF (2011) Reduction of hexachlorobenzene by nanoscale zero-valent iron: kinetics, $\mathrm{pH}$ effect, and degradation mechanism. Sep Purif Technol 76:268-274. https://doi. org/10.1016/j.seppur.2010.10.015

25. Raman CD, Kanmani S (2016) Textile dye degradation using nano zero valent iron: a review. J Environ Manage 177:341-355. https ://doi.org/10.1016/j.jenvman.2016.04.034

26. Babuponnusami A, Muthukumar K (2012) Removal of phenol by heterogenous photo electro Fenton-like process using nanozero valent iron. Sep Purif Technol 98:130-135. https://doi. org/10.1016/j.seppur.2012.04.034

27. Abbassi R, Yadav AK, Kumar N, Huang S, Jaffe PR (2013) Modeling and optimization of dye removal using "green" clay supported iron nano-particles. Ecol Eng 61:366-370. https://doi. org/10.1016/j.ecoleng.2013.09.040

28. Dai Y, Hu Y, Jiang B, Zou J, Tian G, Fu H (2016) Carbothermal synthesis of ordered mesoporous carbon-supported nano zero-valent iron with enhanced stability and activity for hexavalent chromium reduction. J Hazard Mater 309:249-258. https ://doi.org/10.1016/j.jhazmat.2015.04.013

29. Kerkez DV, Tomašević DD, Kozma G, Bečelić-Tomin MR, Prica MD, Rončević SD, Kukovecz Á, Dalmacija BD, Kónya Z (2014) Three different clay-supported nanoscale zero-valent iron materials for industrial azo dye degradation: a comparative study. J Taiwan Inst Chem Eng 45:2451-2461. https://doi.org/10.1016/j.jtice .2014.04.019

30. Wang CB, Zhang WX (1997) Synthesizing nanoscale iron particles for rapid and complete dechlorination of TCE and PCBs. Environ Sci Technol 31:2154-2156. https://doi.org/10.1021/ es970039c

31. Yu R-F, Chi F-H, Cheng W-P, Chang J-C (2014) Application of $\mathrm{pH}$, $\mathrm{ORP}$, and $\mathrm{DO}$ monitoring to evaluate chromium( $\mathrm{VI})$ removal from wastewater by the nanoscale zero-valent iron (nZVI) process. Chem Eng J 255:568-576. https://doi.org/10.1016/J. CEJ.2014.06.002

32. Jamei MR, Khosravi MR, Anvaripour B (2014) A novel ultrasound assisted method in synthesis of NZVI particles. Ultrason Sonochem 21:226-233. https://doi.org/10.1016/j.ultso nch.2013.04.015

33. Li XQ, Zhang WX (2006) Iron nanoparticles: the core-shell structure and unique properties for $\mathrm{Ni}(\mathrm{II})$ sequestration. Langmuir 22:4638-4642. https://doi.org/10.1021/la060057k

34. Bezbaruah AN, Kalita $\mathrm{H}$, Almeelbi $\mathrm{T}$, Capecchi $\mathrm{CL}$, Jacob DL, Ugrinov AG, Payne SA (2014) Ca-alginate-entrapped nanoscale iron: arsenic treatability and mechanism studies. J Nanoparticle Res 16:2175. https://doi.org/10.1007/s11051-013-2175-3

35. Satapanajaru T, Anurakpongsatorn P, Pengthamkeerati $P$, Boparai $\mathrm{H}$ (2008) Remediation of atrazine-contaminated soil and water by nano zerovalent iron. Water Air Soil Pollut 192:349-359. https://doi.org/10.1007/s11270-008-9661-8

36. Chen X, Yao X, Yu C, Su X, Shen C, Chen C, Huang R, Xu X (2014) Hydrodechlorination of polychlorinated biphenyls in contaminated soil from an e-waste recycling area, using nanoscale zerovalent iron and $\mathrm{Pd} / \mathrm{Fe}$ bimetallic nanoparticles. Environ Sci Pollut Res 21:5201-5210. https://doi.org/10.1007/s1135 6-013-2089-8

37. Liu Y, Majetich SA, Tilton RD, Sholl DS, Lowry GV (2005) TCE dechlorination rates, pathways, and efficiency of nanoscale iron particles with different properties. Environ Sci Technol 39:1338-1345. https://doi.org/10.1021/es049195r

38. Mustafa S, Dilara B, Nargis K, Naeem A, Shahida P (2002) Surface properties of the mixed oxides of iron and silica. Colloids Surfaces A Physicochem Eng Asp 205:273-282. https://doi. org/10.1016/S0927-7757(02)00025-0

39. Lucas MS, Peres JA (2006) Decolorization of the azo dye reactive black 5 by fenton and photo-fenton oxidation. Dye Pigment 71:236-244. https://doi.org/10.1016/j.dyepig.2005.07.007

40. Rahmani $\mathrm{H}$, Gholami $\mathrm{M}$, Mahvi AH, Alimohammadi M, Azarian G, Esrafili A, Rahmani K, Farzadkia M (2014) Tinidazole removal from aqueous solution by sonolysis in the presence of hydrogen peroxide. Bull Environ Contam Toxicol 92:341-346. https://doi. org/10.1007/s00128-013-1193-2

41. Kusvuran E, Erbatur $O$ (2004) Degradation of aldrin in adsorbed system using advanced oxidation processes: comparison of the treatment methods. J Hazard Mater 106:115-125. https://doi. org/10.1016/j.jhazmat.2003.10.004

Publisher's Note Springer Nature remains neutral with regard to jurisdictional claims in published maps and institutional affiliations. 